\title{
INTENSITAS NYERI PUNGGUNG BAWAH IBU HAMIL TRIMESTER III YANG MELAKUKAN PRENATAL YOGA
}

\author{
Putu Dyah Pramesti Cahyani ${ }^{1^{\star}}$, Ni Gusti Kompiang Sriasih ${ }^{2^{\star}}$, Made Widhi Gunapria \\ Darmapatni $^{3^{*}}$ \\ (Politeknik Kesehatan Kemenkes Denpasar)
}

\begin{abstract}
Low back pain is musculoscletal problem that causes discomfort during pregnancy. Prenatal yoga is non-pharmacology method that can reduce low back pain. This research aims to find the low back pain difference of third trimester pregnant mothers before and after having prenatal yoga in Bunda Setia clinic. This is pre-experimental research with one group pretest post-test research design. The samples are 36 third trimester pregnant mothers with gestational age of 36-38 weeks who join prenatal yoga in Bunda Setia clinic, chosen by consecutive sampling. The data are taken by observing the level of lower back pain before and after having prenatal yoga. The respondents have prenatal yoga once a week for 2 weeks, 60 minutes duration. The bivariate analysis uses Wilcoxon test $\alpha<0,05$. The median of low back pain before prenatal yoga is 5, after prenatal yoga reduce to 2 with $\rho$ value $=$ $0,000<\alpha(0,05)$ and $Z$ value $(-5.233)$. The conclusion shows there is low back pain level difference of third trimester pregnant mothers before and after having prenatal yoga in Bunda Setia clinic. This intervention is suggested to be applied by medical staff in order to resolve low back pain of pregnant mothers.
\end{abstract}

Keywords: back pain; pregnancy; prenatal yoga

\begin{abstract}
Abstrak
Nyeri punggung bawah selama kehamilan merupakan gangguan muskuloskeletal yang menyebabkan ketidaknyamanan selama kehamilan. Prenatal yoga merupakan metode nonfarmakologi yang dapat mengurangi nyeri punggung bawah. Tujuan penelitian ini untuk mengetahui perbedaan tingkat nyeri punggung bawah ibu hamil trimester III sebelum dengan sesudah melakukan prenatal yoga di Klinik Bunda Setia. Penelitian pre eksperimental dengan rancangan one grup pre-test-posttest design. Sampel yang digunakan yaitu 36 orang ibu hamil trimester III dengan usia kehamilan 36-38 minggu yang mengikuti prenatal yoga di Klinik Bunda Setia yang dipilih secara concecutive sampling. Data diambil dengan melakukan observasi tingkat nyeri punggung bawah sebelum dan sesudah melakukan prenatal yoga. Responden melakukan prenatal yoga satu kali dalam seminggu selama dua minggu dengan durasi 60 menit. Analisis bivariat menggunakan uji Wilcoxon $\alpha<0,05$. Hasil tingkat nyeri punggung bawah sebelum melakukan prenatal yoga diperoleh nilai median 5 dan setelah melakukan prenatal yoga terjadi penurunan median menjadi 2 dengan nilai $\rho=0,000<\alpha(0,05)$ dan nilai $Z$ (-5.233). Simpulannya adalah ada perbedaan tingkat nyeri punggung bawah ibu hamil trimester III sebelum dengan sesudah melakukan prenatal yoga di Klinik Bunda Setia. Intervensi ini disarankan bagi tenaga kesehatan agar menerapkan dalam mengatasi keluhan nyeri punggung pada ibu hamil.
\end{abstract}

Kata kunci : Nyeri punggung; kehamilan; prenatal yoga

\section{PENDAHULUAN}

Kehamilan adalah proses fisiologis yang diawali dengan konsepsi sampai lahirnya janin. Proses kehamilan akan menimbulkan berbagai perubahan pada seluruh sistem tubuh, 
perubahan ini berdampak pada sistem kardiovaskuler, sistem pernafasan, sistem hormonal, sistem gastrointestinal maupun muskuloskeletal ${ }^{1,2}$. Perubahan pada sistem muskuloskeletal selama kehamilan yaitu perubahan tubuh secara bertahap dan peningkatan berat badan dapat menyebabkan keluhan yang nyeri punggung bawah terutama pada trimester III $^{3}$. Selain itu, dari sudut pandang biomekanik, perpindahan pusat gravitasi ke depan meningkatkan hiperekstensi lutut dan ketidakstabilan pelvis ${ }^{4}$. Perubahan tersebut meningkatkan tekanan pada vertebra lumbalis dan tekanan pada otot paraspinal sehingga terjad nyeri punggung bawah.

Nyeri punggung bawah banyak terjadi pada ibu hamil dan mempengaruhi kenyamanan ibu hamil ${ }^{5}$. Menurut penelitian, sekitar $71 \%$ dari 33 ibu hamil mengalamii nyeri punggung bawah pada trimester III kehamilan ${ }^{6}$. Nyeri punggung bawah dapat menyebabkan ketidaknyamanan selama kehamilan sehingga perlu untuk ditangani. Penanganan dapat dilakukan secara farmakologis dan non farmakologis ${ }^{7}$. Salah satu penanganan non farmakologis nyeri punggung bawah selama kehamilan dapat dilakukan dengan prenatal yoga $^{8}$. Prenatal yoga merupakan olah raga yang aman dan efektif membantu ibu hamil untuk mengurangi keluhan kecemasan dan meningkatkan fungsi tulang belakang sehingga dapat mengurangi nyeri punggung bawah ${ }^{9}$.

Klinik Bunda Setia merupakan klinik yang rutin melaksanakan kelas ibu hamil dan prenatal yoga. Berdasarkan studi pendahuluan di Klinik Bunda Setia, sebanyak $70 \%$ ibu hamil mengeluh nyeri punggung bawah.Tujuan penelitian ini adalah untuk mengetahui perbedaan tingkat nyeri punggung bawah ibu hamil trimester III sebelum dengan sesudah melakukan prenatal yoga di Klinik Bunda Setia Denpasar Bali.

\section{METODE PENELITIAN}

Penelitian ini merupakan penelitian pre eksperimental dengan rancangan one group pretest posttest design. Penelitian ini dilakukan di Klinik Bunda Setia yang beralamat di Jalan Jepun Putih No. 2, Denpasar Timur. Penelitian ini dilaksanakan selama satu bulan yaitu dari tanggal 5 April 2019 sampai 3 Mei 2019. Intervensi dilakukan satu minggu sekali selama dua minggu dengan durasi 60 menit dipandu oleh instruktur yoga terlatih. Besar sampel dalam penelitian ini adalah 36 orang ibu hamil Trimester III di Klinik Bunda Setia yang memenuhi kriteria inklusi. Teknik pengambilan sampel dalam penelitian ini adalah non probality sampling jenis consecutive sampling. Pengambilan sampel dilakukan dengan menentukan kriteria inklusi dan eksklusi. Data yang dikumpulkan pada penelitian ini adalah data primer yang diperoleh dari hasil wawancara dengan menggunakan kuesioner dan observasi berdasarkan skala nyeri numerik yang dikombinasikan dengan skala nyeri muka. Hasil uji normalits dengan Shaprowilk dengan nilai $(p)=0,003$, sehingga data berdistribusi tidak normal. Analisis univariat untuk menjelaskan distribusi dan frekuensi masing-masing 
variabel. Uji statistik yang digunakan adalah uji Wilcoxon dengan signifikansi $(\alpha)=0,05$ dan tingkat kepercayaan 95\%. Nilai kemaknaan dalam uji ini adalah $p<0.0$.

\section{HASIL PENELITIAN}

Karakteristik subyek penelitian di Klinik Bunda Setia disajikan pada tabel 1 sebagai berikut :

Tabel 1. Karakteristik Subjek Penelitian di Klinik Bunda Setia Tahun 2019

\begin{tabular}{ccc}
\hline Karakteristik & Frekuensi (f) & Persentase (\%) \\
\hline Umur & 13 & 36,1 \\
$20-25$ & 14 & 38,9 \\
$26-30$ & 9 & 25,0 \\
$31-35$ & 22 & \\
Pekerjaan & 2 & 61,1 \\
Ibu Rumah Tangga & 3 & 5,6 \\
Pegawai Negeri Sipil & 5 & 8,3 \\
Guru & 4 & 13,9 \\
Swasta & 0 & 11,1 \\
Wirausaha & 18 & 0 \\
Pendidikan & 18 & 50 \\
Dasar & & 50 \\
Menengah & & \\
Tinggi & 12 & 33,3 \\
& 24 & 66,7 \\
Paritas & & \\
Primigravida & & \\
Multigravida & &
\end{tabular}

Berdasarkan tabel di atas, umur responden sebagian besar berusia 26-30 tahun $(38,9 \%)$ dan pekerjaan responden sebagian besar adalah ibu rumah tangga yaitu 22 orang (61\%). Pendidikan responden yaitu menengah (SMP/SMA) sebanyak 18 orang (50\%) dan pendidikan tinggi (DIII/S1) sebanyak 18 orang (50\%). Sebagian besar paritas responden adalah multiparitas yaitu sebanyak 24 orang (66,7\%). Hasil uji normalitas data dengan uji Shapiro Wilk menunjukkan data berdistribusi tidak normal, sehingga data disajikan dalam bentuk nilai median, minimum dan maksimum. Hasil observasi tingkat nyeri punggung bawah yang dirasakan oleh 36 responden ibu hamil trimester III sebelum melakukan prenatal yoga disajikan pada tabel 2 .

\section{Tabel 2 Tingkat Nyeri Punggung Bawah Ibu Hamil Trimester III Sebelum Melakukan Prenatal Yoga}

\begin{tabular}{cccccc}
\hline Tingkat Nyeri & Frekuensi (f) & Persentase (\%) & Median & Min & Max \\
\hline 3 & 4 & 11,1 & & & \\
\hline 4 & 8 & 22,2 & & & \\
\hline 5 & 11 & 30,6 & 5 & 3 & 7 \\
\hline 6 & 5 & 13,9 & & & \\
\hline 7 & 8 & 22,2 & & & \\
\hline
\end{tabular}


Berdasarkan tabel 2, sebagian besar responden mengalami nyeri punggung bawah dengan tingkat nyeri lima (nyeri kuat, dalam dan menusuk) yaitu sebanyak 11 orang $(30,6 \%)$. Tingkat nyeri terendah yaitu tiga (sangat terasa namun masih bisa ditoleransi) sebanyak empat orang $(11,1 \%)$ dan tertinggi yaitu tujuh (sangat intens, nyeri lebih mendominasi hingga mempengaruhi beberapa indra) sebanyak delapan orang $(22,2 \%)$ dengan median lima. Hasil pengukuran tingkat nyeri punggung bawah ibu hamil trimester III sesudah melakukan prenatal yoga yaitu sebagai berikut :

\begin{tabular}{|c|c|c|c|c|c|}
\hline $\begin{array}{c}\text { Tingkat } \\
\text { Nyeri }\end{array}$ & $\begin{array}{l}\text { Frekuensi } \\
\text { (f) }\end{array}$ & $\begin{array}{c}\text { Persentase } \\
(\%)\end{array}$ & Median & Min & Max \\
\hline 1 & 7 & 19,4 & \multirow{5}{*}{3} & \multirow{5}{*}{1} & \multirow{5}{*}{5} \\
\hline 2 & 12 & 33,3 & & & \\
\hline 3 & 11 & 30,6 & & & \\
\hline 4 & 4 & 11,1 & & & \\
\hline 5 & 2 & 5,6 & & & \\
\hline
\end{tabular}

Tabel 3 menunjukkan tingkat nyeri punggung bawah ibu hamil trimester III sesudah melakuan prenatal yoga satu minggu sekali selama dua minggu. Sebagian besar responden mengalami nyeri punggung pada tingkat dua (nyeri ringan) sebanyak 12 orang (33,3\%) . Tingkat nyeri punggung tertinggi yaitu lima (nyeri kuat, dalam dan menusuk) sebanyak 2 orang $(5,6 \%)$ dan terendah yaitu satu (sangat ringan) sebanyak tujuh orang $(19,4 \%)$ dengan median dua.Perbedaan tingkat nyeri punggung bawah ibu hamil trimester III sebelum dengan sesudah melakukan prenatal yoga di Klinik Bunda Setia yaitu sebagai berikut :

\begin{tabular}{|c|c|c|c|c|c|c|}
\hline \multirow[t]{2}{*}{ No } & \multirow{2}{*}{$\begin{array}{c}\text { Prenatal } \\
\text { Yoga }\end{array}$} & \multicolumn{3}{|c|}{ Nilai Tingkat Nyeri } & \multirow[b]{2}{*}{ Nilai Z } & \multirow[b]{2}{*}{ Nilai $\rho$} \\
\hline & & Median & Minimum & Maksimum & & \\
\hline 1 & Sebelum & 5 & 3 & 7 & \multirow{2}{*}{$-5,233$} & \multirow{2}{*}{0,0000} \\
\hline 2 & Sesudah & 2 & 1 & 5 & & \\
\hline
\end{tabular}

Berdasarkan tabel 4, terjadi penurunan tingkat nyeri punggung bawah ibu hamil trimester III setelah melakukan prenatal yoga. Nilai median sebelum melakukan prenatal yoga yaitu lima dan sesudah melakukan prenatal yoga menjadi dua. Nilai minimum sebelum melakukan prenatal yoga adalah tiga, kemudian setelah melakukan prenatal yoga menurun menjadi satu. Penurunan juga terjadi pada nilai maksimum yang sebelum melakukan prenatal yoga berada pada tingkat tujuh dan sesudah melakukan prenatal yoga menjadi lima. Hasil analisis bivariat menggunakan uji Wilcoxon didapatkan nilai $Z$ sebesar -5,233 dan nilai $\rho=0,000(\alpha=<0,05)$ yang menunjukkan terdapat perbedaan bermakna pada tingkat nyeri punggung bawah ibu hamil trimester III sebelum dengan sesudah melakukan prenatal 
yoga. Nilai probabilitas $\rho$ value $<0,05$ berarti Ha diterima dan Ho ditolak. Hal ini menujukkan terjadi penurunan tingkat nyeri punggung bawah ibu hamil trimester III setelah melakukan prenatal yoga.

\section{PEMBAHASAN}

Hasil analsis data perbedaan tingkat nyeri punggung bawah ibu hamil trimester III sebelum dengan sesudah melakukan prenatal yoga menunjukkan bawa prenatal yoga dapat menurunkan tingkat nyeri punggung bawah dengan nilai $p=0,000(\alpha<0,05)$. Terdapat penurunan nilai minimum dan maksimum pada tingkat nyeri yang dirasakan responden sebelum dan sesudah melakukan prenatal yoga. Nilai minimum sebelum melakukan prenatal yoga adalah tiga, kemudian setelah melakukan prenatal yoga menurun menjadi satu. Penurunan juga terjadi pada nilai maksimum yang sebelum melakukan prenatal yoga berada pada tingkat tujuh dan sesudah melakukan prenatal yoga menjadi lima. Nilai median sebelum melakukan prenatal yoga yaitu lima dan sesudah melakukan prenatal yoga menjadi dua. Hasil penelitian ini sejalan dengan penelitian sebelumnya, prenatal yoga memberikan efek yang signifikan terhadap penurunan nyeri punggung ibu hamil trimester III. Penelitian lain juga menunjukkan bahwa prenatal yoga merupakan olah raga yang aman dan efektif membantu ibu hamil untuk mengurangi keluhan kecemasan dan nyeri punggung bawah ${ }^{10,11}$.

Gerakan dalam prenatal yoga dapat merangsang produksi hormon endorfin. Berdasarkan Endogenous Opiat Theory tubuh manusia dapat menghasilkan substansi serupa opiate disebut endorfine. Endorfin dapat mempengaruhi transmisi impuls yang diinterpretasikan sebagai nyeri. Endorfine mempengaruhi transmisi impuls yang diinterpretasikan sebagai nyeri. Endorfine kemungkinan bertindak sebagai neurotransmitter maupun neuromodulator yang menghambat transmisi dari pesan nyeri. Endorfin memproduksi analgesia melalui ikatan kepada reseptor opioid di pre dan post sinap ujung saraf terutama berefek melalui ikatan presinap. Ketika berikatan, interaksi akan menghambat pelepasan takikinin terutama substansi $P$, protein kunci yang terlibat pada transmisi nyeri ${ }^{12}$.

Nyeri dapat dirasakan jika reseptor nyeri tersebut menginduksi serabut saraf perifer aferen yaitu serabut A-delta dan serabut $C$. Ketika serabut $C$ dan A-delta menyampaikan rangsang dari serabut saraf perifer maka akan melepaskan mediator biokimia yang aktif terhadap respon nyeri. Transmisi stimulus nyeri berlanjut di sepanjang serabut saraf aferen sampai berakhir di bagian kornu dorsalis medulla spinalis. Didalam kornu dorsalis, neurotransmitter seperti subtansi $P$ dilepaskan sehingga menyebabkan suatu transmisi sinapsis dari saraf perifer ke saraf traktus spinolatamus. Selanjutnya informasi di sampaikan dengan cepat ke pusat thalamus ${ }^{12}$. 
Penurunan tingkat nyeri punggung bawah pada ibu hamil terjadi akibat gerakangerakan yang dilakukan selama prenatal yoga. Gerakan pemusatan perhatian (centering) dan pengaturan pola nafas (pranayama), ibu dapat memfokuskan pikiran dan bernafas dengan tenang dan nyaman sehingga meningkatkan aliran oksigen ke seluruh tubuh ibu dan janin. Selain itu, setelah melakukan prenatal yoga, terdapat penurunan kadar hormon kortisol. Hal tersebut menyebabkan ibu menjadi lebih relaks, dan tenang sehingga respon terhadap nyeri menurun ${ }^{13}$.

Gerakan pemanasan (warming up), peregangan otot dan stabilisasi dapat menurunkan tingkat nyeri punggung bawah pada ibu hamil. Gerakan tersebut dapat membantu relaksasi otot sehingga otot lebih lentur dalam bergerak. Gerakan peregangan akan meningkatkan kelenturan dan kemampuan untuk menggerakkan otot dan persendian. Gerakan pada prenatal yoga membantu ibu untuk membentuk postur tubuh yang baik, sehingga akan terjadi peregangan pada otot, sendi dan tulang belakang. Beberapa gerakan pada prenatal yoga seperti gerakan bitilasana marjarisana (cow and cat pose), ardhakati chakrasana (standing lateral stretch), dan trikonasana (triangle pose) dapat membantu meregangkan otot dan sendi tulang belakang sehingga mengurangi nyeri punggung bawah ${ }^{13}$.

Gerakan relaksasi menyebabkan pikiran dan otot tubuh menjadi lebih rileks, sehingga peredaran darah bekerja dengan baik dan tubuh memproduksi hormon endorfin ${ }^{12}$. Endorfin adalah hormon yang alami yang diproduksi oleh tubuh manusia, maka endorfin adalah penghilang rasa sakit yang terbaik . Endorfin dapat diproduksi secara alami dengan cara melakukan aktivitas seperti meditasi, melakukan pernafasan dalam, makan makanan yang pedas, atau melalui acupuncture treatments atau chiropractic Peningkatan kadar hormon endorfin di dalam tubuh akan menghambat ujung-ujung saraf nyeri, sehingga mencegah stimulus nyeri untuk masuk ke medulla spinalis sehingga sampai ke kortek serebri dan menginterpretasikan kualitas nyeri ${ }^{14}$.

Hasil penelitian ini sesuai dengan hasil peneltian sebelumnya yang menyebutkan bahwa prenatal yoga dapat mengurangi keluhan yang sering dialami selama kehamilan dan memperkuat fisik ibu hamil ${ }^{15}$. Selain itu, prenatal yoga juga aman dan efektif untuk mengurangi nyeri punggung dan untuk meningkatkan kesiapan fisik menghadapi persalinan $^{16}$.

\section{SIMPULAN DAN SARAN}

Berdasarkan hasil penelitian dapat disimpulkan bahwa ada perbedaan tingkat nyeri punggung bawah ibu hamil trimester III sebelum dengan sesudah melakukan prenatal yoga di Klinik Bunda Setia. Disarankan bagi tenaga kesehatan agar menerapkan dalam mengatasi keluhan nyeri punggung pada ibu hamil. 


\section{DAFTAR PUSTAKA}

1. Tyastuti, S. (2016). Asuhan Kebidanan Kehamilan. Jakarta: Kemenkes RI.

2. Fitriana. (2017). Upaya Pemenuhan Rasa Nyaman Pada Ibu Hamil Trimester III dengan Nyeri Punggung. Surakarta: Fakultas Kedokteran Universitas Muhammadiyah Surakarta

3. Fatimah. (2017). Buku Ajar Asuhan Kebidanan Kehamilan. Jakarta: Fakultas Kedokteran dan Kesehatan Universitas Indonesia

4. Emília M, Costa C, Cavalcanti L, Alves C, Terceiro DL, Ravy D. (2017). LOW BACK PAIN DURING PREGNANCY. Brazilian Journal Anesthesiol Vol 63 No 3 Tahun 2017, 266-277.

5. Ibanez G, Khaled A, Jf R, Rohani S, Nizard J, Baiz N. (2017). BACK PAIN DURING PREGNANCY AND QUALITY OF LIFE OF PREGNANT WOMEN. Primary Health Care: Open Access Vol 7 No 1 Tahun 2017, 1-6.

6. Ulfah, M. (2017). HUBUNGAN DIASTASIS RECTI ABDOMINIS DENGAN NYERI PUNGGUNG BAWAH PADA IBU HAMIL. Jurnal Bidan Prada Vol 5 No 2 Tahun 2017, 23-30

7. Herawati, A. (2017). Upaya Penanganan Nyeri Pinggang pada Ibu Hamil Trimester III. Surakarta: Fakultas Kedokteran Universitas Muhammadiyah Surakarta

8. Lestari, P. (2019). PENGARUH KOMBINASI PRENATAL YOGA DAN SENAM HAMIL TERHADAP TINGKAT KECEMASAN DAN LAMA PERSALINAN KALA I PADA IBU HAMIL TRIMESTER III. Indonesian Journal of Midwifery Vol 2 No 2 Tahun 2019, 72-80.

9. Resmi, D.C, Hadisaputro S. (2017). EFFECT OF YOGA AND ACUPRESSURE ON PAIN AND FUNCTIONAL CAPABILITY OF LOWER BACK IN PREGNANT MOTHERS. Belitung Nursing Journal Vol 3 No 6 Tahun 2017, 722-728.

10. Octavia, M.(2018). Pengaruh Senam Yoga Terhadap Nyeri Punggung Bawah Ibu Hamil Trimester III. Yogyakarta : STIKES Yogyakarta

11. Jiang, Q. (2015). EFFECTS OF YOGA INTERVENTION DURING PREGNANCY: A REVIEW FOR CURRENT STATUS EFFECTS OF YOGA INTERVENTION DURING PREGNANCY : A REVIEW FOR CURRENT STATUS. American Journal of Perinatology Vol 32 Tahun 2015, 503-514

12. Sidemen, S. (2016). Peran Endorfin dalam Manajemen Nyeri. Denpasar : Universitas Udayana

13. Rejeki, S.T. (2019). PENGARUH YOGA PRENATAL TERHADAP NYERI PUNGGUNG PADA IBU HAMIL TRIMESTER II DANN III DI LIAA AZZAHRA MOM \& BABY SPA. Indonesia Jurnal Kebidanan Vol 3 No 2 Tahun 2019, 67-72.

14. Suananda, Yhossie. (2017). Prenatal dan Postnatal Yoga. Jakarta : Kompas

15. Widiastini, L., P. (2016). PENGARUH MASSAGE ENDORFIN TERHADAP KECEMASAN IBU HAMIL DALAM MENGHADAPI PROSES PERSALINAN DI 
PUSKESMAS DENPASAR UTARA III. Jurnal Dunia Kesehatan Vol 5 No 2 Tahun 2016, $72-75$

16. Holden SC, Manor B, Zhou J, Zera C, Davis RB, Yeh GY. (2019). PRENATAL YOGA FOR BACK PAIN, BALANCE, AND MATERNAL WELLNESS: A RANDOMIZED , CONTROLLED PILOT STUDY. Global Advance in Health and Medicine Vol 8 No 1 Tahun 2019,1-11. 